\title{
Ultra Structure Study of egg membrane in Osteobrama belangeri
} Val.

\author{
${ }^{1}$ K.Dinesh Singh, ${ }^{2}$ Mrs.W.Mema Devi \\ ${ }^{1}$ Faculty of Science, CMJ University Shillong 793003 Meghalaya \\ ${ }^{2}$ Associate Professor, G P Women's College Imphal 795001 Manipur
}

\begin{abstract}
Osteobrama belangeri (Valenciennes) is a highly prized endemic medium carp available in Yunan province of China, Myanmar and Manipur (North Eastern part of India). The fish attains sexual maturity in 2+ years $(200-25 \mathrm{~g}$. body weight). Investigation of the fine structure of the egg envelope and micropyle of unfertilized spawned eggs of Osteobrama belangeri using Scanning Electron Microscope (SEM) was made. The surface of the egg membrane showed regularly arranged pores. The micropyle is a type II consisting of the flat pit with diameter of micropyle $11 \mu \mathrm{m}$ to $12 \mu \mathrm{m}$ and a long canal narrowing into a distinct canal. The surface of zona radiata was rough with a uniform distribution of round pores with little larger pores around the micropyle region.
\end{abstract}

Key words: chorion, micropyle, reproduction, Osteobrama belangeri, fertilization.

\section{Introduction:}

Osteobrama belangeri is known as Pengba in Manipur and Nga-bpe-oung in Myanmar. It was declared as State fish of Manipur in November 2004. Since then, it has been celebrating "Pengba Day" every year in Manipur. It is a seasonal and riverine spawner that spawns only in river during June and July. This fish species was listed among the 91 endangered fish species of India according to IUCN status and categorized as extinct in the wild (CAMP, 1997).But now some competent fish farmers start culturing this fish and can produce in a minimal quantity.

Ultra structural characteristics of the chorion and the micropyle of teleost eggs differ in different species and have recently been considered as a criterion for identification of eggs (Ohta et al.,1983; Chen et al.,2007). Shape number and size of micropyle and also reinforcement type of the micropyle canal; the number and length of the longest and shortest ridge in the micropyle region; the diameter, number and arrangement of the accessory opening; the adhesive structures of egg and mode of them to the substrate; ornamentation and the thickness of the membrane have been used for taxonomic purposes (Hirai and Yamamoto, 1986; Riehl, 1993; Giulialnini et al.; 1994; Bless and Rieh1,2002; Esmaeili and Johal, 2005; Huysentruyt and Adriaens, 2005; Chen et al., 2007 Costa and Leal, 2009 ). Since the envelope of fish egg is relatively thick, the acrosome less fish sperm gains access to the ooplasmic surface through micropyle, a pore at the animal pole of the egg.

As majority of the teleost sperm lack acrosome, species - species reaction between the sperm and the egg does not naturally occur during fertilization. The size of the sperm head and the diameter of the micropylar canal prevents hybridization between different genera and different species during mixed spawning (Jamieson, 1991).But among Indian major carps (catla, rohu, mrigal and calbasu) both intergeneric and interspecific fertile hybrids are commonly encountered (Mishra et al; 1998) and morphological identification of some of the hybrids is often confusing (A.Gopalakrishnan; 2002)

The present study was aimed at preparation of a base - line image of surface structure of Osteobrama belangeri and their fertile reciprocal hybrids.
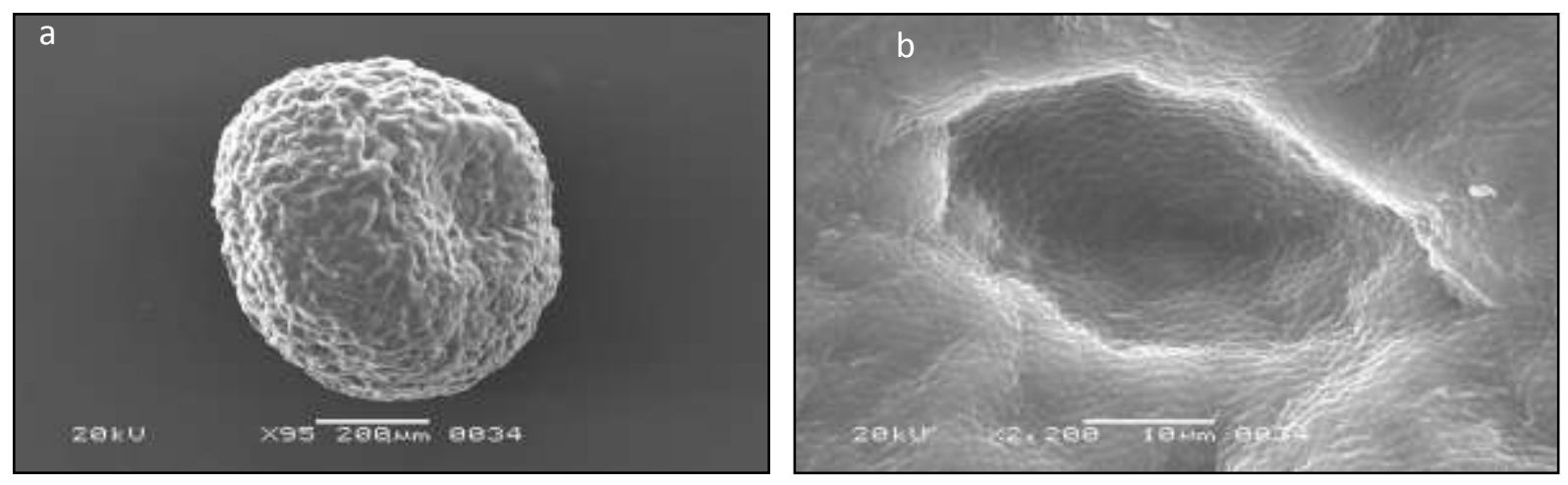

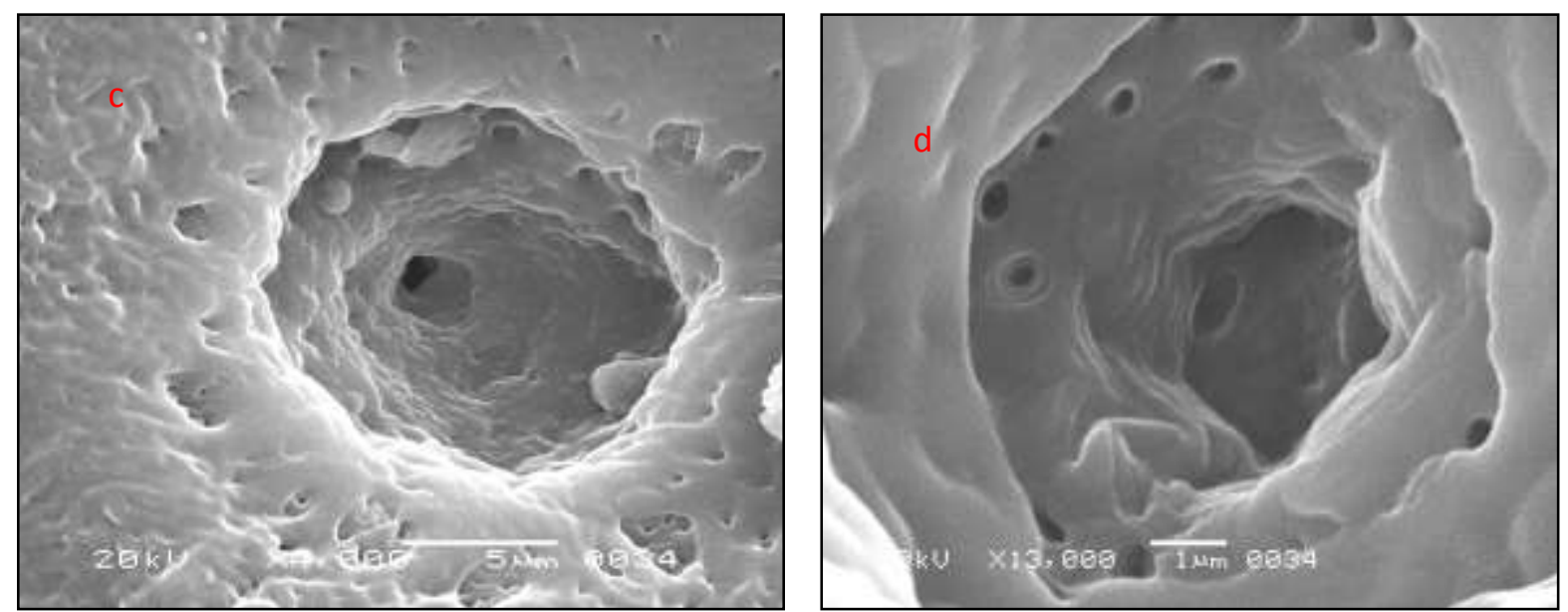

Fig. Scanning electron microscope (SEM) pictures of egg surface structures of Osteobrama belangeri (a) Whole view of the egg (b) Regular distribution of oval pores on the egg surface (c) Magnification view of micropyle (d) Higher magnification of micropyle region showing oval micropylar canal, accessory pores in pit around of it and zona radiata.

\section{Material And Methods:}

To investigate the morphology and surface ultra structure of micropyle of ripe eggs, we caught female specimen of Osteobrama belangeri from Nambul River, Imphal, Manipur $\left(23^{\circ} 50^{\prime} \mathrm{N}\right.$ and $25^{\circ} 41^{\prime} \mathrm{N}$ latitudes and $93^{\circ} 03^{\prime} \mathrm{E}$ and $94^{\circ} 78^{\prime} \mathrm{E}$ longitudes) which flows into Loktak Lake, which is the largest fresh water lake in the North Eastern India. Over the last 45 years its wild population has undergone a drastic decline and is presently found missing in the Loktak lake and other water bodies of central plains of Manipur. It is perhaps due to loss of habitat after the construction of Ithai barrage on the Imphal River for supply of water to the Loktak HydroElectric Project. The barrage possibly prevented the breeding migration of the fish from the Southern parts of Manipur River, which ultimately flows into the Chindwin in Myanmar.

For SEM study, we collect ripe eggs from female Osteobrama belangeri spawner's by hand stripping. The fishes were released unharmed after the eggs were collected. The collected eggs were initially washed in fish saline buffer $\left(0.14 \mathrm{M} \mathrm{NaCl}, 0.01 \mathrm{M} \mathrm{KCl}, 0.16 \mathrm{mM} \mathrm{MgCl}_{2}, 5 \mathrm{mM} \mathrm{CaCl}_{2}, 1.8 \mathrm{mM} \mathrm{Na}_{2} \mathrm{PO}_{4}, 2 \mathrm{mM}\right.$ $\mathrm{NaHCO}_{3}, 5 \mathrm{mM}$ Glusose ) then fixed in the fixative of $5 \%$ glutaraldehyde with $4 \%$ paraformaldehyde in $0.1 \mathrm{M}$ phosphate buffer at $\mathrm{pH} 7.5$ for $4 \mathrm{hrs}$ at $4^{\circ} \mathrm{C}$. The eggs were changed to phosphate buffer $(0.1 \mathrm{M}, \mathrm{pH} 7.4)$ for 48 hrs. The samples are dried on a blotting paper for 10 minutes at room temperature and mounted on Brass stubs and sputter coated with gold of about $35 \mathrm{~nm}$ thick in a Sputter machine. The specimens were studied in a Scanning Electron Microscope (SEM; JSM- 6360 JEOL) under an accelerating voltage of $20 \mathrm{KV}$

\section{Results And Discussion:}

The unfertilized eggs of Osteobrama belangeri were oval in shape (Fig.a).The diameter of the egg is range around $600 \mu \mathrm{m}$ to $620 \mu \mathrm{m}$. The eggs were enveloped by a relatively thick zona radiata (5.1 $\mu \mathrm{m}$ to 5.3 $\mu \mathrm{m})$. The surface of the zona radiate was wavy with a uniform distribution of almost round pores of $0.25 \mu \mathrm{m}$ to $0.26 \mu \mathrm{m}$ in diameter at a density of 640 pores $/ 100 \mu \mathrm{m}^{2}$.(Fig.b). Apart from other Cyprinidae family, the egg did not content ridges around the micropyle (Fig.c). The uniform distribution of pores is slightly larger near the opening of the micropyle. The outer opening of the micropyle canal had a diameter of $11 \mu \mathrm{m}$ to $12 \mu \mathrm{m}$. The micropyle region was flat (Fig.c) The micropyle was almost circular in shape and the micropyle canal was narrowing into a distinct canal of $1 \mu \mathrm{m}$. (Fig.c) Round or oval pores of around $0.33 \mu \mathrm{m}$. were also observed around and inside the canal (Fig. d) the micropyle was of type II as there is flat pit and canal is long. Some of the agglutinates were also observed near the micropyle region. In spite of a great similarity between the eggs of Cyprinidae family, the ultra structure of micropyle and egg membranes differed greatly and were species specific.The diameter of the micropyle canal (4.5 um) of rohu egg is larger than the size of the sperm head of both rohu (1.9 um) and mrigal (2.2 um) (Gopalakrishnan et al., 2002) thus giving a clear scientific explanation for the free access of spermatozoom without any acrosomal complex (Verma et al. 2009) of other cyprinids into rohu eggs producing hybrids. The narrow canal inside the micropyle and absent of ridges around the micropyle is something which do not found in other Cyprinidae family. So it needs to investigate the ultra structure of spermatozoa of Osteobrama belangeri to find out the co-relation of their gametes .Further study is still going on. 


\section{Acknowledgements:}

We are grateful to DR.Sundiv Dey (SO),Mr.Nari.K.Rynjah (STA) and Dr. Rahul Chakraborty (STA)of Sophisticated Analytical Instrument Facility (SAIF) North-Eastern Hill University (NEHU)Sillong 793022 for providing the facilities. Lastly we would like to thank Department of Zoology, GP Women's Collage,Imphal Manipur for their support and co-orporation.

\section{References:}

[1] Bless, R. and Riehl, R., 2002. Biology and egg morphology of the Dalmatian barbelgudgeon Aulopyge huegeli, an endangered endemic species in Croatia. Environmental Biology of Fishes, 63, 451-456.

[2] CAMP,1997. Draft. Conservation assessments \& Management Plan Workshop for freshwater fishes of India. National Bureau of Fish Genetic Research (NBFGR), Lucknow, Sept. 22-26.

[3] Chen, C. H., Wu, C. C., Shao, K. T. and Yang, J. S., 2007. Chorion microstructure for identifying five fish eggs of Apogonidae. Journal of Fish Biology, 71, 913-919.

[4] Costa, W. J. E. M. and Leal, F., 2009. Egg surface morphology in the Neotropical seasonal killifish genus Leptolebias (Teleostei: Aplocheiloidei: Rivulidae). Vertebrate Zoology, 59, 25-29.

[5] Esmaeili, H. R. and Johal, M. S., 2005. Ultrastructural features of the egg envelope of silver carp, Hypophthalmichthys molitrix (Osteichthyes, Cyprinidae). Environmental Biology of Fishes, 72, 373-377.

[6] Esmaeili, H. R. and Gholamifard. A. 2012. Ultrastructur of the chorion and the micropyle of an endemic cyprinid fish, Cyprinion tenuiradius Heckel, 1849 (Teleostei: Cyprinidae ) from southern Iran. Iranian Journal of Fisheries Sciences, 11(3),657-665.

[7] Jamieson, B.G.M. 1991. Fish Evolution and Systematics: Evidence from Spermatozoa. Cambridge University Press, Cambridge, U.K.,319 pp

[8] Giulianini, P. G., Marcotullio, A. D., Ferrero, E. A. and Patzner, R. A., 1994. Light microscopical and ultrastructural cytology of the ovaries in the sea-grass goby Zosterisessor ophiocephalus (Osteichthyes, Gobiidae). Italian Journal of Zoology, 61(2), 135144 .

[9] Gopalakrishnan, A., A.G. Ponniah and K.K. Lal 2002. Ultrastructure of egg membrane of rohu (Labeo rohita ) .Indian J. Fish 49(1), 93-95.

[10] Hirai, A. and Yamamoto, T. S., 1986. Micropyle in the developing eggs of the Anchovy, Engraulis japonica. Japanese Journal of Ichthyology, 33, 62-66.

[11] Huysentruyt, F. and Adriaens, D., 2005. Adhesive structures in the eggs of Corydoras aeneus (Gill, 1858; Callichthyidae). Journal of Fish Biology, 66, 871-876.

[12] Mishra, A., A.K. Jain and S.P .Singh 1998. Rate of spontaneous hybridization in mixed spawning of Indian major carps. In: Fish Genetics and Biodiversity Conservation, Natcon Spl. Publn. 5, A.G.Ponniah, P. Das, \& S. R. Verma (Ed.),National Conservators, Muzaffarnagar, U.P

[13] Ohta, H., Takano, K., Izawa, T. and Yamauchi, K., 1983. Ultrastracture of the Chorion and the Micropyle of the Japanese Eel Anguilla japonica. Bulletin of the Japanese Society of Scientific Fisheries, 49(3), 501.

[14] Riehl, R., 1993. Surface morphology and micropyle as a tool for identifying fish eggs by scanning electron microscopy. European Microscopy and Analysis, 23, 7-9. 